\title{
Setup System of Selective Roll Cooling Based on Profile Prediction in Aluminum Hot Strip Mill
}

Jian Shao, Chihuan Yao, Wenquan Sun Anrui He

National Engineering Research Center of Advanced Rolling, University of Science and Technology Beijing. China.

E-mail: ustbshao@163.com

In aluminum strip production, profile formed in hot rolling is critical to flatness control in the subsequent cold rolling, and selective work roll cooling is marked by the flexible control of complex high-order shape defects. Therefore, a setup system of selective cooling is developed to achieve the whole cross-section profile control in hot rolling. It includes a real-time work roll thermal model based on finite deference method and a strip profile predictive model based on RBF network. A spray pattern is obtained using an iteration method, as the "basic pattern" for the setup, for the situation when roll thermal contour need to be maintained. Based on the predicted profile error, adjustment of the basic pattern is made by fuzzy inference to get the final setup spray pattern, under which the profile error can be reduced during the threading.

Keywords: Shape Control, Work Roll Cooling, Finite Deference Method, RBF Network.

\section{Acknowledgement}

This work was supported by the National Natural Science Foundation of China (No.51404021) and the Beijing Municipal Natural Science Foundation (No.3154035).

\section{References}

[1] MEIJER, O., BALLYNS, J., POWERS, R., VIGNONE, J., KUEBER, P. (1989). Aluminum hot mill work roll cooling control. In: Conference Record - IAS Annual Meeting (IEEE Industry Applications Society), pp. 1425 - 1430. IEEE, USA.

[2] PUCHNIN, M., ANISIMOV, E., CEJP, J., KUNKA, I., VICENS, S. (2014). Advantages of express-methods in investigation of mechanical and physical properties of aluminum alloys. In: Manufacturing Technology, Vol. 14, No. 2, pp. 234-238. UJEP, Czech Republic.

[3] LV, Z. F., QU, D. B. (2011). Profile control strategy in aluminum alloy hot strip tandem rolling. In: Nonferrous Metals Processing, Vol. 40, No. 5, pp. 21 - 24. CNIA, China.

[4] POSTLETHWAITE, I., ATACK, P. A., ROBINSON, I. S. (1996). Improved control for an aluminium hot reversing mill using the combination of adaptive process models and an expert system. In: Journal of Materials Processing Technology, Vol. 60, No. 1 - 4, pp. 393 - 398. Elsevier, Amsterdam.

[5] CAMPOS, A. M., GARCÍD, F., ABAJO, N. DE, GONZÁLEZ, J. A. (2004). Real-time rule-based control of the thermal crown of work rolls installed in hot strip mills. In: IEEE Transactions on Industry Applications, Vol. 40, No. 2, pp. 642 - 649. IEEE, USA.

[6] WANG, Y. D., YU, B., LIU, H. M., PENG, Y. (2004). Evaluation and control of hot-rolled strip profile. In: Iron and Steel, Vol. 46, No. 9, pp. 50 - 54. Metalurgical Industry Press, Beijing.

[7] NIE, Y. D., WU, L. (2009). Analysis on automatic crown control system of "1+4” hot tandem. In: Aluminium Fabrication, No. 2, pp. 4 - 7. CNIA, China.

[8] GUO, X. Y., HE, A. R., SHAO, J., ZHOU, B., LI, Q. L. (2013). Modeling and simulation of subsectional cooling system during hot aluminum rolling. In: Journal of Mechanical Engineering, Vol. 49, No. 4, pp. 70 - 74. Chinese Mechanical Engineering Society, Beijing.

[9] WANG, L. S., YANG, Q., HE, A. R., ZHENG, X., YU, H. R. (2010). Improvement of prediction model for work roll thermal contour in hot strip mill. In: Journal of Central South University of Technology (English Edition), Vol. 17, No. 6, pp. 1251 1257. Central South University of Technology, China.

[10] GHODSI, A., SCHUURMANS, D. (2003). Automatic basis selection techniques for RBF networks. In: Neural Networks, Vol. 16, No. 5 - 6, pp. 809 - 816. Elsevier, Amsterdam.

[11] MAŇKOVÁ, I., VRABEL', M., KOVAC, P. (2013). Artificial neural network application for surface roughness prediction when drilling nickel based alloy. In: Manufacturing Technology, Vol. 13, No. 2, pp. 193-199. UJEP, Czech Republic.

[12] KUŚMIERCZAK, S., NÁPRSTKOVÁ, N., KUBA, M. (2014). Analysis of the Defects Causes in Rolled Brass Sheet. In: Manufacturing Technology, Vol. 14, No. 3, pp. 347-351. UJEP, Czech Republic.

[13] LAMPARIELLO, F., SCIANDRONE, M. (2001). Efficient training of RBF neural networks for pattern recognition. In: IEEE Transactions on Neural Networks, Vol. 12, No. 5, pp. 1235 - 1242. IEEE, USA. 